\title{
Responses to Temperatures of Different Drosophila Species
}

2 Ainul Huda ${ }^{1 *}$, Thomas J. Vaden ${ }^{1 *}$, Alisa A. Omelchenko ${ }^{1 *}$, Allison N. Castaneda ${ }^{1}$, Lina Ni $^{1 \#}$

$3{ }^{1}$ School of Neuroscience, Virginia Polytechnic Institute and State University, Blacksburg,

4 Virginia, USA

$5 *$ equal contribution

$6 \quad$ \# corresponding author

$7 \quad$ E-mail: linani@vt.edu

ORCiD: 0000-0003-2155-5155

Key words: Drosophila, thermosensation, thermotaxis, warm avoidance, cool avoidance

\section{Summary statement}

13 The ability to move and the preference for temperatures vary among fly species when flies are

14 exposed to steep temperature gradients.

16 Abstract

17 Temperature is a critical environmental variable that affects the distribution, survival, and 18 reproduction of most animals. Although temperature receptors have been identified in different 19 animals, how these receptors respond to temperatures is largely unknown. Here we use modified 20 single-fly thermotactic assays to analyze movements and temperature preferences of nine 21 Drosophila species. The ability/inclination to move varies among these species and at different 22 temperatures. Importantly, different species prefer various ranges of temperatures. While wild23 type $D$. melanogaster flies avoid the warm temperature in the warm avoidance assay and the cool 24 temperature in the cool avoidance assay, D. bipectinata and D. yakuba avoid neither warm nor 25 cool temperatures and D. biarmipes and D. mojavensis do not avoid the warm temperature in the 26 warm avoidance assay. These results demonstrate that Drosophila species have different mobilities 27 and temperature preferences, thereby benefiting the research on molecular mechanisms of 28 temperature responsiveness. 
31 Temperature affects all aspects of physiology, from the rate of chemical reactions and the activity of biomolecules to the distribution of living organisms (Dell et al., 2011, Sengupta and Garrity, 2013, Franks and Hoffmann, 2012). Temperature variation is particularly influential for small animals, such as insects, which depend on ambient temperatures to set their body temperatures (Garrity et al., 2010, Dillon et al., 2010). Many insect vectors of diseases, including mosquitoes, respond to the temperature of their warm-blooded hosts and use it to guide blood-feeding behaviors (Brown, 1951, Howlett, 1910, Corfas and Vosshall, 2015, Greppi et al., 2015, Greppi et al., 2020).

Fruit flies are a good insect model system to study thermosensation. In D. melanogaster, many thermosensory systems are governed by a small number of sensory neurons but control robust behaviors (Ni et al., 2013, Hamada et al., 2008, Klein et al., 2015, Budelli et al., 2019, Gallio et al., 2011). These sensory neurons possess evolutionarily conserved thermal molecules across Drosophila species and with insect vectors of diseases, including mosquitoes (Corfas and Vosshall, 2015, Greppi et al., 2020). Adult D. melanogaster flies possess several thermosensory systems to control different thermotactic behaviors (Barbagallo and Garrity, 2015). Aristal warm and cool neurons guide rapid warm and cool avoidance when flies are exposed to steep temperature gradients. A gustatory receptor GR28B(D) is the warm receptor in aristal warm neurons and three members from the Ionotropic Receptor (IR) family (IR25a, IR93a, and IR21a) form the cool receptor in aristal cool neurons (Ni et al., 2013, Budelli et al., 2019). However, molecular mechanisms underlying how these thermoreceptors respond to temperatures are largely unknown.

Besides D. melanogaster, genomes of more than 20 other Drosophila species have been sequenced (Celniker et al., 2002, Hoskins et al., 2007, Hu et al., 2013, Clark et al., 2007, Stark et al., 2007, Chen et al., 2014). These sequenced species span a wide range of global distributions with diverse temperatures (Powell, 1997). Therefore, they may possess thermoreceptors that have evolved distinct temperature responsiveness through amino-acid changes at a few residues to adapt to their specific ecosystems. We thereby expect that they will offer opportunities to understand how thermoreceptors respond to temperatures.

This study modifies single-fly thermotactic assays and uses TrackMate to track fly movement (Budelli et al., 2019, Tinevez et al., 2017). Using these assays, we test 801 flies from temperatures and genders affect preference indices and identify several Drosophila species 
61 mimicking temperature preferences of $D$. melanogaster thermoreceptor mutants. These results may benefit the research about molecular mechanisms of temperature responsiveness.

\section{Results}

\section{Drosophila species have diverse mobilities}

66 To understand temperature responses of different Drosophila species by thermotactic assays, we first analyzed their mobilities. Using single-fly warm and cool avoidance assays, we tested 801 flies, including four genotypes of $D$. melanogaster as controls, D. ananassae, D. biarmipes, $D$. bipectinata, D. erecta, D. ficusphila, D. mojavensis, D. simulans, and D. yakuba. A single fly was acclimated under a transparent cover (this cover is $83 \mathrm{~mm}$ (length) X 58mm (width) X 2mm (height) and thus flies can only walk, but not fly) at $25 \pm 1^{\circ} \mathrm{C}$ for $2 \mathrm{~min}$ and then allowed to explore between zones of $25 \pm 1^{\circ} \mathrm{C}$ and $31 \pm 1^{\circ} \mathrm{C}$ or $11 \pm 1^{\circ} \mathrm{C}$ for $2 \mathrm{~min}$. Their positions were recorded by TrackMate and moving distances were calculated. Next, we analyzed moving distances by pseudo-F statistics and identified 10 clusters. Flies in the cluster with the least moving distances moved from 107.584 to 799.243 pixels. Independent visual analysis by four researchers agreed that flies in this cluster had limited mobilities; flies in other clusters were able to adequately explore both temperatures (Movie 1). 800 pixels was set as the threshold (the dashed line in Fig. 1). Flies that had moving distances shorter than 800 pixels were omitted from preference index (PI) analysis.

Most fly species moved significantly more in the warm avoidance assay than in the cool avoidance assay, including WCS D. melanogaster, D. ananassae, D. biarmipes, D. bipectinata, D. erecta, D. mojavensis, D. simulans, and D. yakuba (Fig. 1). These data suggest that flies are more active in warm environments.

Moreover, fly species had diverse mobilities. In the warm avoidance assay, D. erecta moved the least and D. mojavensis moved the most. The average moving distance of $D$. erecta was about $1 / 15$ of $D$. mojavensis. In the cool avoidance assay, $D$. erecta still moved the least, while the most active flies were $D$. melanogaster $\operatorname{Ir} 93 a^{M I}$, whose average moving distance was over 31 times that of D. erecta (Fig. 1). Of note, in the warm avoidance assay, moving distances from more than half of D. ananassae and D. erecta flies did not reach the threshold (Fig. 1) and were not further analyzed. Similarly, in the cool avoidance assay, less than half of $D$. ananassae, D. erecta, and $D$. 


\section{Starting temperatures and genders affect PIs}

Next, we tried to understand the effects of starting temperatures and genders in PIs using wildtype WCS D. melanogaster. The PI was calculated by dividing the difference of the time spent at $25^{\circ} \mathrm{C}$ and the time spent at $31^{\circ} \mathrm{C}$ or $11^{\circ} \mathrm{C}$ by the total time. A positive PI indicates preference for $25^{\circ} \mathrm{C}$, while a negative PI indicates preference for $31^{\circ} \mathrm{C}$ or $11^{\circ} \mathrm{C}$; PI near zero suggests no preference.

We divided $W C S$ data from the warm avoidance assay into four groups: males starting at $25^{\circ} \mathrm{C}$, females starting at $25^{\circ} \mathrm{C}$, males starting at $31^{\circ} \mathrm{C}$, and females starting at $31^{\circ} \mathrm{C}$. As shown in Fig. 2A, males and females had similar PIs when they started at the same temperatures. When flies started at different temperatures, PIs were significantly different. Flies that started at $25^{\circ} \mathrm{C}$ had strong preferences for $25^{\circ} \mathrm{C}$, while flies that started at $31^{\circ} \mathrm{C}$ had no preferences between $25^{\circ} \mathrm{C}$ and

$10331^{\circ} \mathrm{C}$. These data suggest that starting temperatures, but not genders, affect PIs in the warm 104 avoidance assay.

In the cool avoidance assay, we also divided $W C S$ data into four groups: males starting at $25^{\circ} \mathrm{C}$, females starting at $25^{\circ} \mathrm{C}$, males starting at $11^{\circ} \mathrm{C}$, and females starting at $11^{\circ} \mathrm{C}$ (Fig. 2B). When flies started at $25^{\circ} \mathrm{C}$, males had much a stronger preference for $25^{\circ} \mathrm{C}$ than female flies. This difference was not observed when they started at $11^{\circ} \mathrm{C}$. Moreover, males that started at $25^{\circ} \mathrm{C}$ strongly preferred $25^{\circ} \mathrm{C}$ and males that started at $11^{\circ} \mathrm{C}$ had no preferences between $25^{\circ} \mathrm{C}$ and $11^{\circ} \mathrm{C}$.

110 For females, flies that started at $25^{\circ} \mathrm{C}$ had an average PI that was higher than those that started at

$11111^{\circ} \mathrm{C}$. But these two groups were not significantly different. Therefore, in the cool avoidance assay, 112 both starting temperatures and genders affect PIs. In the following analysis, to understand the 113 temperature preference of each fly species, males and females were separated and only flies that 114 started at $25^{\circ} \mathrm{C}$ were analyzed.

\section{D. biarmipes, $D$. bipectinata, $D$. mojavensis, and $D$. yakuba don't avoid warm temperatures}

117 Finally, we calculated PIs of different fly species. As mentioned, only flies that started at $25^{\circ} \mathrm{C}$ 118 were used. We tested four D. melanogaster genotypes: two wild types, WCS and HCS; a cool 119 receptor mutant, $\operatorname{Ir} 93 a^{M I}$; and a warm receptor mutant, Gr28b $b^{M B}$ (Knecht et al., 2016, Budelli et 120 al., 2019, Ni et al., 2013). In the warm avoidance assay, both male and female $W C S$ and $H C S$ 121 strongly preferred $25^{\circ} \mathrm{C}$ (Fig. 3A,B). PIs of $G r 28 b^{M B}$ were significantly lower than that of $W C S$, 122 which is consistent with previous reports (Ni et al., 2013, Simões et al., 2021, Budelli et al., 2019) 
(Fig. 3A,B). D. biarmipes, D. bipectinata, and D. yakuba had similar PIs with Gr $28 b^{M B}$, suggesting that these species don't have preferences between $25^{\circ} \mathrm{C}$ and $31^{\circ} \mathrm{C}$ (Fig. 3A,B). D. mojavensis flies had a negative average PI, indicating they prefer $31^{\circ} \mathrm{C}$ (Fig. 3A,B).

\section{D. bipectinata and D. yakuba don't avoid cool temperatures}

128 In the cool avoidance assay, male $W C S$ and $H C S$ strongly preferred $25^{\circ} \mathrm{C}$ (Fig. 3C). As reported 129 previously (Enjin et al., 2016, Budelli et al., 2019), cool receptor mutant $\operatorname{Ir} 93 a^{M I}$ males had a lower 130 average PI than WCS males (Fig. 3C). Average PIs of D. ficusphila and D. yakuba males were 131 close to 0 , indicating they have no preferences between $25^{\circ} \mathrm{C}$ and $11^{\circ} \mathrm{C}$ (Fig. 3C). D. bipectinata 132 males had a negative average PI, suggesting they prefer $11^{\circ} \mathrm{C}$ (Fig. $3 \mathrm{C}$ ).

133 Regarding female flies, $W C S$ and $H C S$ also preferred $25^{\circ} \mathrm{C}$ (Fig. 3D). Unexpectedly, $134 \operatorname{Ir} 93 a^{M I}$ females had a similar average PI with WCS females. D. bipectinata and D. yakuba females, 135 like their males, had PIs close to 0 , indicating they have no preferences between $25^{\circ} \mathrm{C}$ and $11^{\circ} \mathrm{C}$ 136 (Fig. 3D). On the other hand, D. ficusphila females behaved differently from their males: $D$. 137 ficusphila males had no preferences between $25^{\circ} \mathrm{C}$ and $11^{\circ} \mathrm{C}$ but their females had strong 138 preferences for $25^{\circ} \mathrm{C}$. These data further suggest that genders affect PIs, at least in the cool 139 avoidance assay.

\section{Discussion}

142 In this study, we modify single-fly thermotactic assays and use TrackMate to track fly movements.

143 We test 801 flies, including four genotypes of $D$. melanogaster and eight other Drosophila species.

144 We find that fly species have different temperature preferences from wild-type D. melanogaster.

145 Wild-type D. melanogaster flies avoid the high temperature of $31^{\circ} \mathrm{C}$ in the warm avoidance assay 146 and the cool temperature of $11^{\circ} \mathrm{C}$ in the cool avoidance assay. D. bipectinata and D. yakuba avoid 147 neither warm nor cool temperatures and D. biarmipes and D. mojavensis don't avoid the warm 148 temperature in the warm avoidance assay. Our results also show that starting temperatures and 149 genders affect PIs.

150 Most fly species move significantly more in warmer environments than in cool 151 environments. But this isn't true for the cool receptor mutant $\operatorname{Ir} 93 a^{M I}$ and the warm receptor mutant $152 G r 28 b^{M B}$ (Knecht et al., 2016, Budelli et al., 2019, Ni et al., 2013). In these two mutants, moving 153 distances are similar in both assays. Moreover, these two mutants move significantly more than 
wild-type D. melanogaster WCS (Fig. 1). Reasons that cause these phenomena are unknown. One possibility is that these mutants per se move more. This possibility can be tested by measuring their moving distances in environments with unique temperatures. Gr $28 b^{M B}$ supports this possibility and it moves more than $W C S$ in $25^{\circ} \mathrm{C}$ (Omelchenko et al., 2021). An alternative possibility is that $\operatorname{Ir} 93 a^{M I}$ and $G r 28 b^{M B}$ move more only when they are allowed to explore different temperature zones. In this case, temperature receptors help animals not only choose an optimal temperature but also save energy. Further studies are needed to test these possibilities.

According to $W C S$ data, starting temperatures affect PIs. The only pair that isn't significantly different is females that start at $25^{\circ} \mathrm{C}$ and $11^{\circ} \mathrm{C}$ in the cool avoidance assay. Even in this case, the average PI of the former group is higher than that of the latter group (Fig. 2B). Moreover, genders also affect PIs, at least in the cool avoidance assay. For example, in the cool avoidance assay, $W C S$ males have stronger preferences for $25^{\circ} \mathrm{C}$ than their female counterparts when they start at $25^{\circ} \mathrm{C}$ (Fig. 2B). In addition, D. ficusphila males have no preferences between $25^{\circ} \mathrm{C}$ and $11^{\circ} \mathrm{C}$ but females have strong preferences for $25^{\circ} \mathrm{C}$ (Fig. 3C,D).

GR28BD is the warm receptor that controls warm avoidance when flies are exposed to a steep gradient (Ni et al., 2013, Simões et al., 2021, Budelli et al., 2019). As expected, Gr28b ${ }^{M B}$ has defects in the warm avoidance assay, but not in the cool avoidance assay (Fig. 3). IR93a is a component of the cool receptor that is required for flies to avoid cool temperatures upon exposure to a steep gradient and its mutant has been reported to be deficient in avoiding both warm and cool temperatures (Enjin et al., 2016, Budelli et al., 2019, Knecht et al., 2016). In our warm avoidance assay, $\operatorname{Ir} 93 a^{M I}$ flies have lower, but not significantly different PIs compared to WCS (Fig. 3A,B). The difference may be because we only analyze flies that start at $25^{\circ} \mathrm{C}$. In the cool avoidance assay, Ir93 $a^{M I}$ males have PIs that are significantly lower than WCS males (Fig. 3C), which is consistent with previous studies. However, Ir93 $a^{M I}$ females have a similar average PI with $W C S$ females (Fig. 3D). We suspect that this is because WCS females have lower PIs (Fig. 2B) or our cool avoidance assay uses a lower temperature in the cool zone than the previous study (Budelli et al., 2019). Of note, IR25a is another cool receptor component and its mutant doesn't have defects in avoiding $10^{\circ} \mathrm{C}$ (Enjin et al., 2016). Further studies on the functions of the cool receptor are needed.

183 show different temperature preferences from $D$. melanogaster. In the cool avoidance assay, $D$. 
from these species may offer opportunities to understand how thermoreceptors respond to different temperatures.

In summary, this study uses behavioral assays to understand fly temperature preferences and identifies fly species that have different temperature preferences from $D$. melanogaster. In the future, temperature preferences of other fly species should be analyzed and thermosensory organs, neurons, and molecular receptors should be compared among different fly species to understand mechanisms underlying temperature preferences.

\section{Materials and methods}

\section{Drosophila strains:}

195 White Canton-S (WCS) was used as the wild-type D. melanogaster control. Heisenberg Canton-S

$196(H C S)$ and D. mojavensis were kind gifts from Dr. Michael Dickinson. Ir93a ${ }^{M I}$ (Knecht et al., 2016) 197 and $G r 28 b^{M B}$ (Ni et al., 2013) were previously reported. Other fly species were from the National 198 Drosophila Species Stock Center: D. ananassae (14024-0371.11), D. biarmipes (14023-0361.03), D. bipectinata (14024-0381.21), D. erecta (14021-0224.05), D. ficusphila (14025-0441.01), D. simulans (14021-0251.011), and D. yakuba (14021-0261.48).

\section{Thermotactic behavioral assay:}

203 Flies were raised at $25^{\circ} \mathrm{C}$ under 12-hour light/12-hour dark cycles and were $3 \pm 1$ days from eclosure when experiments were performed. All experiments were performed between 8:00 am and 12:00 pm. Fly species that were deemed difficult to distinguish sex via the naked eye were observed and divided under a microscope using a cold plate 24 hours in advance. The warm avoidance assay was performed as described (Omelchenko et al., 2021). Experimental procedures for cool avoidance behavioral assays were identical to previously mentioned procedures, apart from replacing the right-side hot plate with a glass casserole dish filled with ice, with more ice placed on top of the steel plate with the left plate temperature set to $25 \pm 1^{\circ} \mathrm{C}$ and the right plate to $11 \pm 1^{\circ} \mathrm{C}$.

212 ImageJ and analyzed by TrackMate as described (Tinevez et al., 2017, Omelchenko et al., 2021).

213 The preference index was calculated by the following formula:

$$
\mathrm{PI}=\frac{\left(\text { time in } 25^{\circ} \mathrm{C}\right)-\left(\text { time in } 31^{\circ} \mathrm{C} \text { or } 11^{\circ} \mathrm{C}\right)}{\text { Total time }}
$$




\section{Short Communications}

Thermosensation of Different Fly Species

A Python script was developed to calculate moving distances and preference indices.

216

\section{Statistical analysis:}

218 Statistical details of experiments are mentioned in the figure legends. The normality of

219 distributions was assessed by the Shapiro-Wilk W test ( $p \leq 0.05$ rejected normal distribution).

220 Statistical comparisons of normally distributed data were performed by the Welch's t test. For data

221 that did not conform to a normal distribution, statistical comparisons were performed by the Mann-

222 Whitney test. Data analysis was performed using GraphPad Prism 9. The pseudo-F statistics was 223 performed by R. 
Short Communications

Thermosensation of Different Fly Species

\section{Acknowledgements}

226 We acknowledge Dr. Jianhong Ou for the R script for the pseudo-F statistics, Dr. Michael

227 Dickinson for HCS and D. mojavensis flies.

228

\section{Competing interest}

230 No competing interests declared

231

\section{Funding}

233 This work was supported by the National Institutes of Health (R21MH122987 to L.N. and 234 R01GM140130 to L.N.).

235

236 Data availability

237 The Python script has been deposited in GitHub and can be accessed at: 238 https://github.com/niflylab/SingleFlyAnalysis.git. 
Short Communications

Thermosensation of Different Fly Species

\section{References}

BARBAGALLO, B. \& GARRITY, P. A. 2015. Temperature sensation in Drosophila. Curr Opin Neurobiol, 34, 8-13.

BROWN, A. W. 1951. Factors in the attractiveness of bodies for mosquitoes. Nature, 167, 202.

BUDELLI, G., NI, L., BERCIU, C., VAN GIESEN, L., KNECHT, Z. A., CHANG, E. C., KAMINSKI, B., SILBERING, A. F., SAMUEL, A., KLEIN, M., BENTON, R., NICASTRO, D. \& GARRITY, P. A. 2019. Ionotropic Receptors Specify the Morphogenesis of Phasic Sensors Controlling Rapid Thermal Preference in Drosophila. Neuron.

CELNIKER, S. E., WHEELER, D. A., KRONMILLER, B., CARLSON, J. W., HALPERN, A., PATEL, S., ADAMS, M., CHAMPE, M., DUGAN, S. P., FRISE, E., HODGSON, A., GEORGE, R. A., HOSKINS, R. A., LAVERTY, T., MUZNY, D. M., NELSON, C. R., PACLEB, J. M., PARK, S., PFEIFFER, B. D., RICHARDS, S., SODERGREN, E. J., SVIRSKAS, R., TABOR, P. E., WAN, K., STAPLETON, M., SUTtTON, G. G., VENTER, C., WEINSTOCK, G., SCHERER, S. E., MYERS, E. W., GIBBS, R. A. \& RUBIN, G. M. 2002. Finishing a whole-genome shotgun: release 3 of the Drosophila melanogaster euchromatic genome sequence. Genome Biol, 3, Research0079.

CHEN, Z. X., STURGILL, D., QU, J., JIANG, H., PARK, S., BOLEY, N., SUZUKI, A. M., FLETCHER, A. R., PLACHETZKI, D. C., FITZGERALD, P. C., ARTIERI, C. G., ATALLAH, J., BARMINA, O., BROWN, J. B., BLANKENBURG, K. P., CLOUGH, E., DASGUPTA, A., GUBBALA, S., HAN, Y., JAYASEELAN, J. C., KALRA, D., KIM, Y. A., KOVAR, C. L., LEE, S. L., LI, M., MALLEY, J. D., MALONE, J. H., MATHEW, T., MATTIUZZO, N. R., MUNIDASA, M., MUZNY, D. M., ONGERI, F., PERALES, L., PRZYTYCKA, T. M., PU, L. L., ROBINSON, G., THORNTON, R. L., SAADA, N., SCHERER, S. E., SMITH, H. E., VINSON, C., WARNER, C. B., WORLEY, K. C., WU, Y. Q., ZOU, X., CHERBAS, P., KELliS, M., EISEN, M. B., PIANO, F., KIONTE, K., FITCH, D. H., STERNBERG, P. W., CUTTER, A. D., DUFF, M. O., HOSKINS, R. A., GRAVELEY, B. R., GIBBS, R. A., BICKEL, P. J., KOPP, A., CARNINCI, P., CELNIKER, S. E., OLIVER, B. \& RICHARDS, S. 2014. Comparative validation of the D. melanogaster modENCODE transcriptome annotation. Genome Res, 24, 1209-23.

CLARK, A. G., EISEN, M. B., SMITH, D. R., BERGMAN, C. M., OLIVER, B., MARKOW, T. A., KAUFMAN, T. C., KELLIS, M., GELBART, W., IYER, V. N., POLLARD, D. A., SACKTON, T. B., LARRACUENTE, A. M., SINGH, N. D., ABAD, J. P., ABT, D. N., ADRYAN, B., AGUADE, M., AKASHI, H., 
Short Communications

Thermosensation of Different Fly Species

ANDERSON, W. W., AQUadro, C. F., ARDEll, D. H., ARgUello, R., ARTIERI, C. G., BARBASH, D. A., BARKER, D., BARSANTI, P., BATTERHAM, P., BATZOGLOU, S., BEGUN, D., BHUTKAR, A., BLANCO, E., BOSAK, S. A., BRADLEY, R. K., BRAND, A. D., BRENT, M. R., BROOKS, A. N., BROWN, R. H., BUTLIN, R. K., CAGGESE, C., CALVI, B. R., BERNARDO DE CARVAlHO, A., CASPI, A., CASTREZANA, S., CELNIKER, S. E., CHANG, J. L., CHAPPLE, C., CHATterJI, S., CHINWALlA, A., CIVETTA, A., CLIFTON, S. W., COMERON, J. M., COSTEllO, J. C., COYNE, J. A., DAUB, J., DAVID, R. G., DELCHER, A. L., DELEHAUNTY, K., DO, C. B., EBLING, H., EDWARDS, K., EICKBUSH, T., EVANS, J. D., FILIPSKI, A., FINDEISS, S., FREYHULT, E., FULTON, L., FULTON, R., GARCIA, A. C., GARDINER, A., GARFIELD, D. A., GARVIN, B. E., GIBSON, G., GILBERT, D., GNERRE, S., GODFREY, J., GOOD, R., GOTEA, V., GRAVELY, B., GREENBERG, A. J., GRIFFITHS-JONES, S., GROSS, S., GUIGO, R., GUSTAFSON, E. A., HAERTY, W., HAHN, M. W., HALLIGAN, D. L., HALPERN, A. L., HALTER, G. M., HAN, M. V., HEGER, A., HILLIER, L., HINRICHS, A. S., HOLMES, I., HOSKINS, R. A., HUBISZ, M. J., HULTMARK, D., HUNTLEY, M. A., JAFFE, D. B., JAGADEESHAN, S., et al. 2007. Evolution of genes and genomes on the Drosophila phylogeny. Nature, 450, 203-18.

CORFAS, R. A. \& VOSSHALL, L. B. 2015. The cation channel TRPA1 tunes mosquito thermotaxis to host temperatures. Elife, 4.

DELL, A. I., PAWAR, S. \& SAVAGE, V. M. 2011. Systematic variation in the temperature dependence of physiological and ecological traits. Proc Natl Acad Sci U S A, 108, 10591-6.

DILLON, M. E., WANG, G. \& HUEY, R. B. 2010. Global metabolic impacts of recent climate warming. Nature, 467, 704-6.

ENJIN, A., ZAHARIEVA, E. E., FRANK, D. D., MANSOURIAN, S., SUH, G. S., GALLIO, M. \& STENSMYR, M. C. 2016. Humidity Sensing in Drosophila. Curr Biol, 26, 1352-8.

FRANKS, S. J. \& HOFFMANN, A. A. 2012. Genetics of Climate Change Adaptation. Annual Review of Genetics, 46, 185-208.

GALLIO, M., OFSTAD, T. A., MACPHERSON, L. J., WANG, J. W. \& ZUKER, C. S. 2011. The coding of temperature in the Drosophila brain. Cell, 144, 614-24. 
Short Communications

Thermosensation of Different Fly Species

GARRITY, P. A., GOODMAN, M. B., SAMUEL, A. D. \& SENGUPTA, P. 2010. Running hot and cold: behavioral strategies, neural circuits, and the molecular machinery for thermotaxis in C. elegans and Drosophila. Genes Dev, 24, 2365-82.

GREPPI, C., BUDELLI, G. \& GARRITY, P. A. 2015. Some like it hot, but not too hot. Elife, 4.

GREPPI, C., LAURSEN, W. J., BUDELLI, G., CHANG, E. C., DANIELS, A. M., VAN GIESEN, L., SMIDLER, A. L., CATTERUCCIA, F. \& GARRITY, P. A. 2020. Mosquito heat seeking is driven by an ancestral cooling receptor. Science, 367, 681-684.

HAMADA, F. N., ROSENZWEIG, M., KANG, K., PULVER, S. R., GHEZZI, A., JEGLA, T. J. \& GARRITY, P. A. 2008. An internal thermal sensor controlling temperature preference in Drosophila. Nature, 454, 217-20.

HOSKINS, R. A., CARLSON, J. W., KENNEDY, C., ACEVEDO, D., EVANS-HOLM, M., FRISE, E., WAN, K. H., PARK, S., MENDEZ-LAGO, M., ROSSI, F., VILLASANTE, A., DIMITRI, P., KARPEN, G. H. \& CELNIKER, S. E. 2007. Sequence finishing and mapping of Drosophila melanogaster heterochromatin. Science, 316, 1625-8.

HOWLETT, F. M. 1910. The Influence of Temperature upon the Biting of Mosquitoes. Parasitology, 3, 479-484.

HU, T. T., EISEN, M. B., THORNTON, K. R. \& ANDOLFATTO, P. 2013. A second-generation assembly of the Drosophila simulans genome provides new insights into patterns of lineage-specific divergence. Genome Res, 23, 89-98.

KLEIN, M., AFONSO, B., VONNER, A. J., HERNANDEZ-NUNEZ, L., BERCK, M., TABONE, C. J., KANE, E. A., PIERIBONE, V. A., NITABACH, M. N., CARDONA, A., ZLATIC, M., SPRECHER, S. G., GERSHOW, M., GARRITY, P. A. \& SAMUEL, A. D. 2015. Sensory determinants of behavioral dynamics in Drosophila thermotaxis. Proc Natl Acad Sci U S A, 112, E220-9.

KNECHT, Z. A., SILBERING, A. F., NI, L., KLEIN, M., BUDELLI, G., BELL, R., ABUIN, L., FERRER, A. J., SAMUEL, A. D., BENTON, R. \& GARRITY, P. A. 2016. Distinct combinations of variant ionotropic glutamate receptors mediate thermosensation and hygrosensation in Drosophila. Elife, 5. 
Short Communications

Thermosensation of Different Fly Species

NI, L., BRONK, P., CHANG, E. C., LOWELL, A. M., FLAM, J. O., PANZANO, V. C., THEOBALD, D. L., GRIFFITH, L. C. \& GARRITY, P. A. 2013. A gustatory receptor paralogue controls rapid warmth avoidance in Drosophila. Nature, 500, 580-4.

OMELCHENKO, A. A., HUDA, A., CASTANEDA, A. N., VADEN, T. J. \& NI, L. 2021. Using TrackMate to Analyze Drosophila Larval and Adult Locomotion. bioRxiv, 2021.09.28.462241.

POWELL, J. R. 1997. Progress and Prospects in Evolutionary Biology: The Drosophila Model. Oxford University Press, Incorporated.

SENGUPTA, P. \& GARRITY, P. 2013. Sensing temperature. Curr Biol, 23, R304-7.

SIMÕES, J. M., LEVY, J. I., ZAHARIEVA, E. E., VINSON, L. T., ZHAO, P., ALPERT, M. H., KATH, W. L., PARA, A. \& GALLIO, M. 2021. Robustness and plasticity in Drosophila heat avoidance. Nat Commun, 12, 2044.

STARK, A., LIN, M. F., KHERADPOUR, P., PEDERSEN, J. S., PARTS, L., CARLSON, J. W., CROSBY, M. A., RASMUSSEN, M. D., ROY, S., DEORAS, A. N., RUBY, J. G., BRENNECKE, J., HODGES, E., HINRICHS, A. S., CASPI, A., PATEN, B., PARK, S. W., HAN, M. V., MAEDER, M. L., POLANSKY, B. J., ROBSON, B. E., AERTS, S., VAN HELDEN, J., HASSAN, B., GILBERT, D. G., EASTMAN, D. A., RICE, M., WEIR, M., HAHN, M. W., PARK, Y., DEWEY, C. N., PACHTER, L., KENT, W. J., hAUSSLER, D., LAI, E. C., BARTEL, D. P., HANNON, G. J., KAUFMAN, T. C., EISEN, M. B., CLARK, A. G., SMITH, D., CELNIKER, S. E., GELBART, W. M. \& KELLIS, M. 2007. Discovery of functional elements in 12 Drosophila genomes using evolutionary signatures. Nature, 450, 219-32.

TINEVEZ, J. Y., PERRY, N., SCHINDEliN, J., HOOPES, G. M., REYNOLDS, G. D., LAPLANTINE, E., BEDNAREK, S. Y., SHORTE, S. L. \& ELICEIRI, K. W. 2017. TrackMate: An open and extensible platform for single-particle tracking. Methods, 115, 80-90. 
Short Communications

Thermosensation of Different Fly Species

Figures

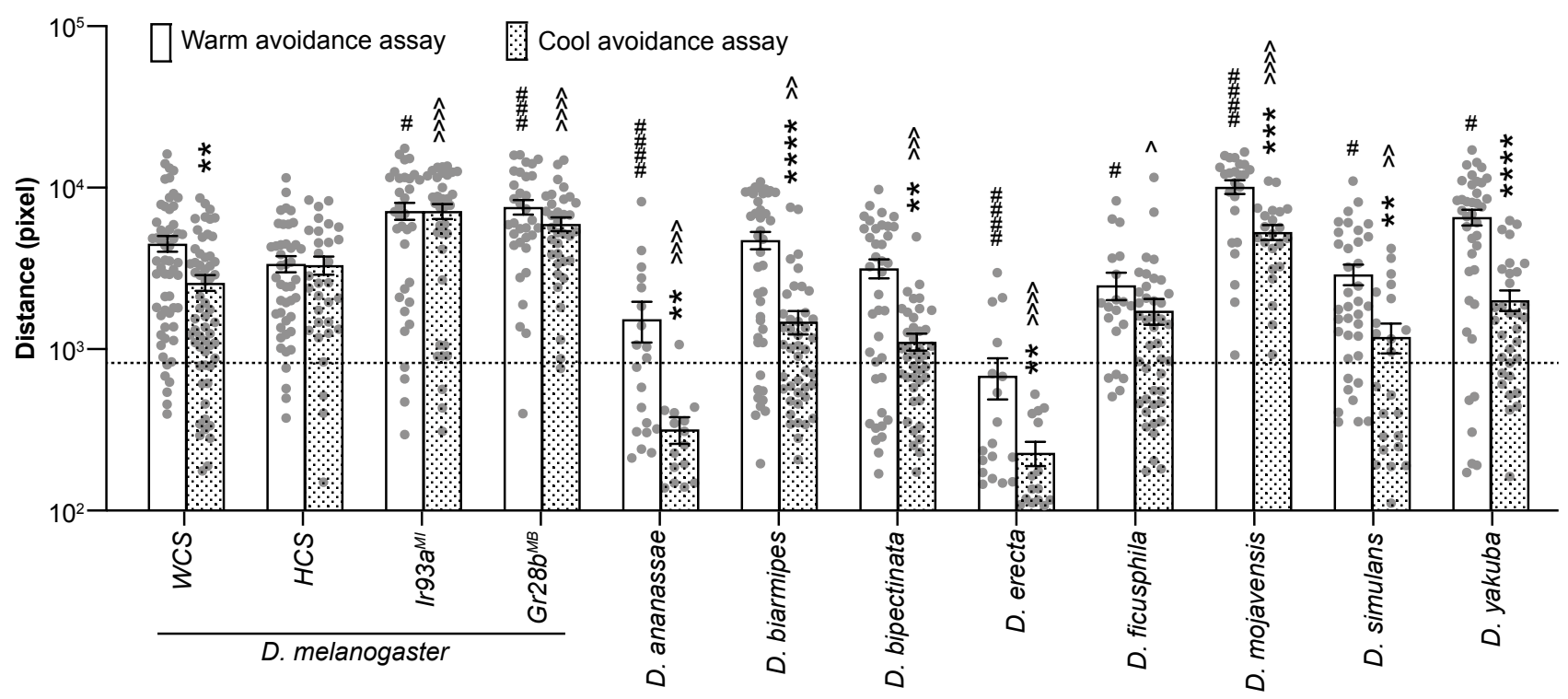

353 Fig 1. Drosophila species have diverse mobilities. Four genotypes (WCS, HCS, $\operatorname{Ir} 93 a^{M I}$, and $354 G r 28 b^{M B}$ ) of D. melanogaster, as well as D. ananassae, D. biarmipes, D. bipectinata, D. erecta, 355 D. ficusphila, D. mojavensis, D. simulans, and D. yakuba were tested. The dashed line shows the 356 threshold of the moving distance, 800 pixels. Data represent mean \pm SEM. $* * p<0.01, * * * p<$ 3570.001 , and $* * * * p<0.0001$; comparing moving distances of the corresponding genotype/species 358 in the warm avoidance assay; Mann-Whitney test, except Welch's test for $G r 28 b^{M B}$. \# $p<0.05$, 359 \#\#\# $p<0.001$, and \#\#\#\# $p<0.0001$; comparing moving distances of WCS in the warm avoidance 360 assay; Mann-Whitney test. ${ }^{\wedge} p<0.05,{ }^{\wedge \wedge} p<0.01,{ }^{\wedge \wedge \wedge} p<0.001$, and ${ }^{\wedge \wedge \wedge} p<0.0001$; comparing 361 moving distances of $W C S$ in the cool avoidance assay; Mann-Whitney test. 
Short Communications

Thermosensation of Different Fly Species

A WCS warm avoidance

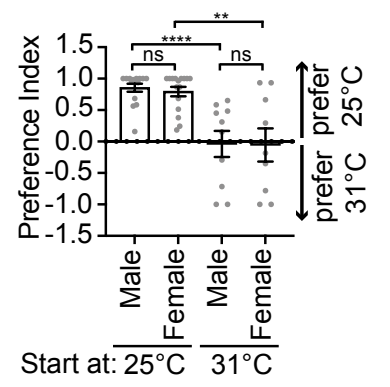

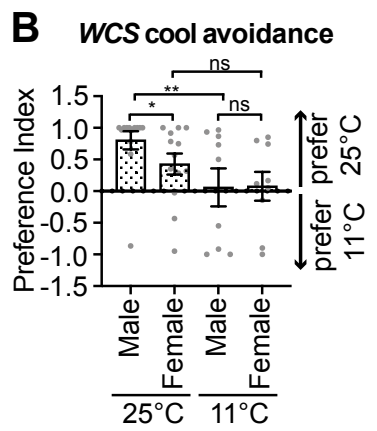

363 Fig 2. Both starting temperatures and genders affect WCS PIs. PIs of indicated groups in warm

364 (A) and cool (B) avoidance assays. Data represent mean $\pm \mathrm{SEM} . * p<0.05, * * p<0.01$, and $* * * *$

$365 p<0.0001$; Mann-Whitney test, except Welch's test for the comparison of males starting at $31^{\circ} \mathrm{C}$

366 and females starting at $31^{\circ} \mathrm{C}$ in (A) and the comparison of females starting at $25^{\circ} \mathrm{C}$ and females

367 starting at $11^{\circ} \mathrm{C}$ in (B). 
Short Communications

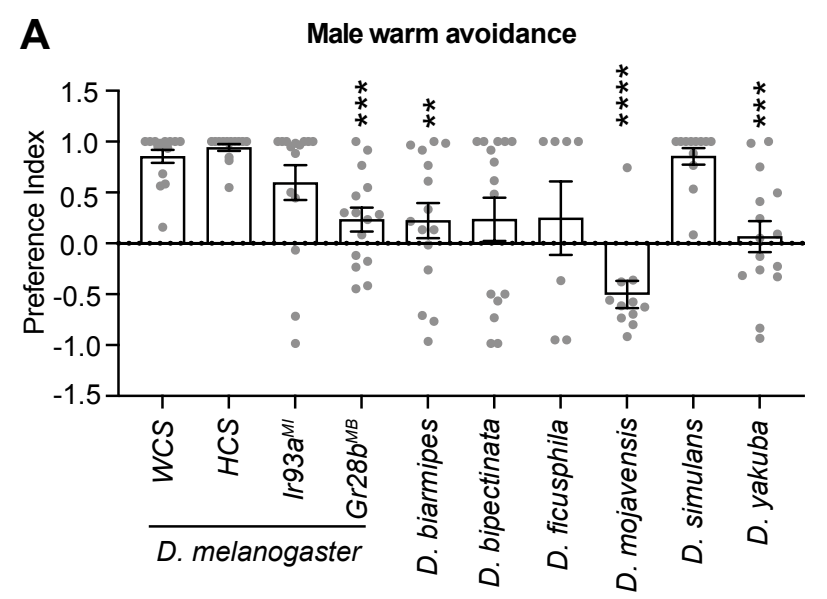

C

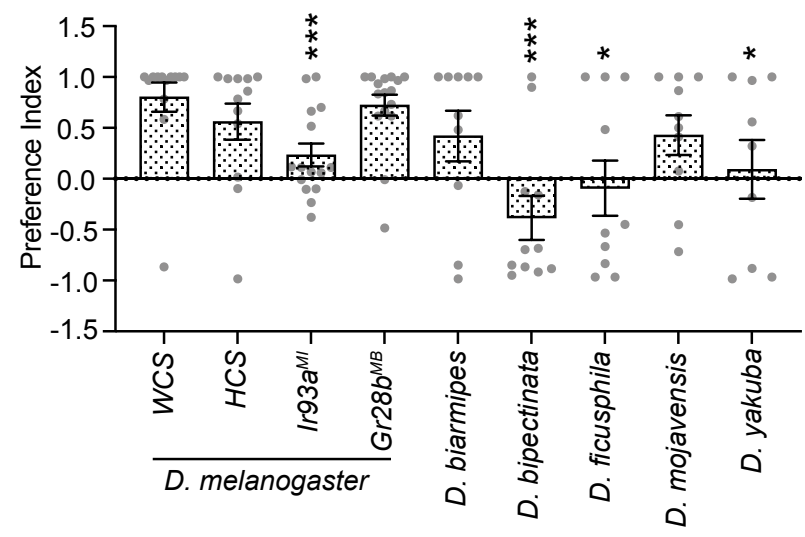

Thermosensation of Different Fly Species

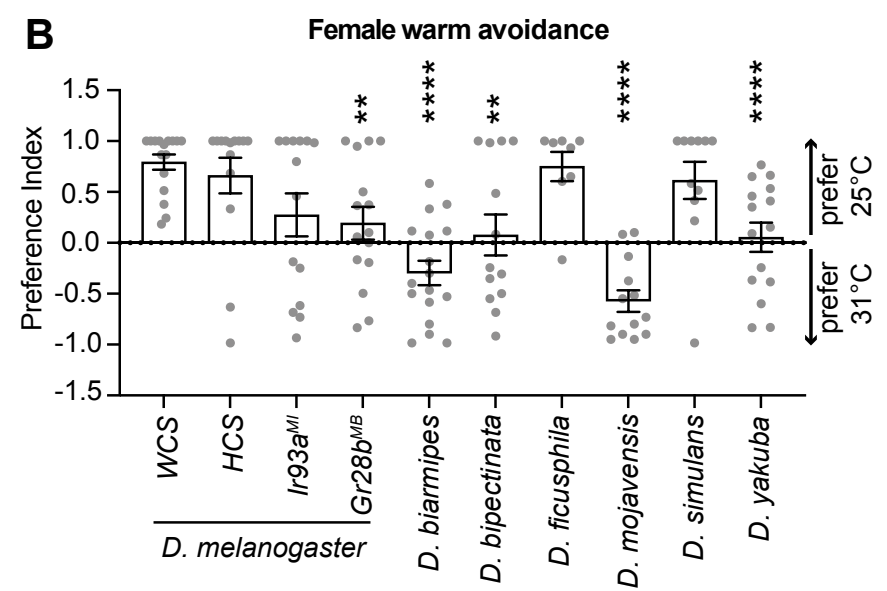

D Female cool avoidance

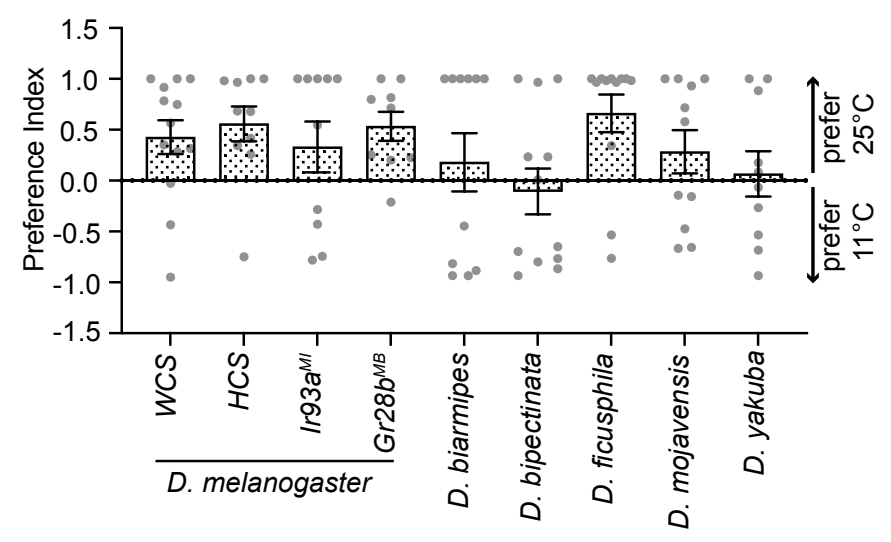

369 Fig 3. Drosophila species have distinct temperature preferences. (A,B) PIs of males (A) and

370 females (B) of indicated D. melanogaster genotypes or Drosophila species in the warm avoidance

371 assay. (C,D) PIs of males (C) and females (D) of the indicated D. melanogaster genotypes or

372 Drosophila species in the cool avoidance assay. Data represent mean \pm SEM. * $p<0.05$, ** $p<$

$3730.01, * * * p<0.01$ and $* * * * p<0.0001$; comparing to the corresponding WCS; Mann-Whitney

374 test, except Welch's test for the comparison of WCS and Gr28b ${ }^{M B}$ and $W C S$ and D. yakuba in (B). 
bioRxiv preprint doi: https://doi.org/10.1101/2021.10.01.462748; this version posted October 2, 2021. The copyright holder for this preprint (which was not certified by peer review) is the author/funder. All rights reserved. No reuse allowed without permission.

Short Communications

Thermosensation of Different Fly Species

375 Movie 1. Set the threshold value for moving distances. Example trajectories from flies with

376 moving distances of about 250 pixels, 450 pixels, 650 pixels, 850 pixels, and 1050 pixels.

377 Trajectories are shown in red. 